\title{
ASPEK AKUNTANSI KEHIDUPAN PENGEMIS DI DESA PRAGAAN DAYA KECAMATAN PRAGAAN KABUPATEN SUMENEP
}

\author{
Ainor Rofiqie ${ }^{1}$, Norsain ${ }^{2}$, Mohammad Herli ${ }^{3}$ \\ ${ }^{1,2,3)}$ Fakultas Ekonomi dan Bisnis Universitas Wiraraja \\ Email:afiazizie@gmail.com ${ }^{1}$,norsain@wiraraja.ac.id ${ }^{2}$, mohammadherli@wiraraja.ac.id ${ }^{3}$
}

\begin{abstract}
ABSTRAK
Penelitian ini mengeksplorasi paradigma masyarakat di Pragaan Daya Madura dalam hal tradisi mengemisnya. Studi ini dilandasioleh kenyataan bahwa mengemis bukan lagi merupakan solusi tentatif bagiproblem ekonomi mereka, melainkan telah menjadi pekerjaan tetap untuk memenuhi beban hidup. Dengan menggunakan pendekatan etnografi, kajianini berupaya menjawab persoalan utama, yakni latar belakang kehidupan pengemis dan motif akuntansi di dalamnya.

Dalam penelitian ini analisis yang dilakukan untuk mengetahui pengelolaan keuangan pengemis dan dapat dilakukan berdasarkan persamaan akuntansi, akan tetapi dalam penerapannya tidak semua akun yang terdapat dalam persamaan akuntansi digunakan dalam pengelolaan keuangan akuntansi pengemis. Praktik akuntansi pengemis hanya dibutuhkan penerimaan dan pengeluaran secara kasarnya saja.
\end{abstract}

Kata Kunci: Tradisi, Akuntansi, Mengemis.

\section{INTRODUCTION}

Indonesia sebagai negara berkembang mengantongi berbagai ragam persoalan, mulai dari persoalan humaniora, ekonomi, politik hingga budaya. Problematika humaniora yang muncul tidak mengenal letak geografis dan struktur sosial, sehingga sering ditemukan ketimpangan sosial diberbagai sudut daerah baik di kawasan metropolis maupun pedesaan. Sebagai negara agraris sekaligus maritim indonesia menjadi salah satu negara yang sangat potensial untuk berevolusi menjadi negara maju, namun ditengah peperangan digital negara indonesia tidak mampu untuk mengoptimalkan peluang besar tersebut dengan hanya menjadi penonton dari setiap perubahan yang diciptakan. Sumber daya alam yang melimpah tidak didukung dengan sumber daya manusia yang kompeten, sehingga menimbulkan persoalan yang berkepanjangan salah satu diantaranya terkait kemiskinan.
Bersarangnya kemiskinan di Indonesia menjadi perbincangan publik yang tidak dapat dihindari, karena secara eksplisit kemiskinan merupakan beban terberat untuk negara Indonesia. secara garis besar faktor kemiskinan yang terjadi di kalangan masyarakat meliputi keterbatasan fisik dan mental, tidak adanya skill, sikap malas dan angka putus sekolah yang cukup tinggi. Beberapa faktor tersebut mengakibatkan lahirnya pengangguran yang menjadi cikal bakal persoalan ekonomi secara komprehensif. berdasarkan data yang dilansir dari Badan Pusat Statistik Nasional persentase pengangguran di negara Indonesia Pada tahun 2017 menempati angka 7,01\%, sedangkan jumlah penduduk miskin untuk daerah sumenep mencapai 211,920 jiwa.

Tingginya persentase pengangguran di daerah sumenep menjadi problematika besar daerah, mengingat kebutuhan hidup yang semakin meningkat setiap waktu dengan 
mayoritas sumber daya manusia yang tidak berpenghasilan. Tuntutan sosial demi melangsungkan kehidupan tidak menemukan solusi yang tepat kecuali dengan cara yang instan, Hal tersebut dilakukan dengan cara mengemis. Untuk menjadi pengemis tidak membutuhkan skill khusus dan modal finansial yang besar, cukup dengan berpenampilan dekil dan kotor seorang pengemis akan mendapatkan simpati dari masyarakat untuk memberikan sumbangsih finanasial secara sukarela. Dalam melaksanakan aksinya pengemis hanya akan memilih tempat yang cukup ramai seperti pasar, lampu merah, sampai menyosori daerah perkampungan.

Asumsi diatas mengilustrasikan pengemis dengan segala keterbatasan akan tetapi terdapat fenomena menarik yang dapat di jumpai di desa pragaan daya kecamatan pragaan kabupaten sumenep, dengan hampir seluruh masyarakatnya mengemis sebagai sumber penghasilan. Dalam merealisasikan aksi mengemis, masyarakat pragaan daya menyebar diberbagai sudut kota dan desa di kabupaten sumenep. ketika pembahasan terkait pengemis hanya untuk masyarakat dengan keterbatasan ekonomi dan skill, berbeda dengan pengemis pragaan daya yang notabene berasal dari kalangan srtata sosial menengah keatas. Konkritisi statement tersebut dapat direalitaskan dengan tidak ditemukan atmosfer kemiskinan dan banyaknya sarang penyakit busung lapar dan rendahnya tingkat pendidikan akibat keterbatasan finansial ataupun kekurangan sandang dan papan atau rumah.

Atmosfer kemiskinan nyaris tidak ditemukan disudut kampung pragaan daya kecuali rumah yang layak dihuni dengan anak-anak yang berpendidikan, bahkan terdapat salah satu anak dari penduduk kampung pragaan daya yang mengenyam pendidikan di salah satu fakultas favorit dari universitas bergengsi di Indonesia. realitas terkait kontradiksi pengemis dengan segala kemampuan finansial yang dimiliki menggiring persepsi baru bahwa kemiskinan yang terjadi di daerah pragaan daya tidak lagi berorientasi kepada finansial melainkan kemiskinan mental yang berkepanjangan.

Konsep kemiskinan mental disini berarti pengemis yang tergolong mampu secara finansial namun tetap mengemis sebagai sumber penghasilan utama karena malas untuk bekerja dan tidak memiliki skill khusus yang dapat menjadi daya tawar masyarakat. Dari statement dan realitas tersebut dapat diasumsikan bahwa pengemis adalah profesi bukan lagi solusi tentaif bagi masyarakat kampung pragaan. Profesi mengemis disini dilakukan secara turun menurundan berevolusi menjadi kultur masyarakat kampung pragaan sehingga kampung tersebut dijuluki 'kampung pengemis'.

Secara aplikatif konsep mengemis masyarakat pragaan dilakukan dengan cara berkelompok yang dikoordinatori oleh satu orang. Setiap kelompok pengemis tersebut akan tersebar diberbagai sudut kota dan pedesaan sesuai dengan tempat yang dispekati untuk melaksanakan aksinya. Dalam melancarkan aksinya pengemis tersebut juga membutuhkan biaya-biaya yang tidak terlalu besar sebagai modal awal dalam melaksanakan kegiatannya. Selain mengeluarkan biaya-biaya, pengemis juga akan mendapatkan penghasilan yang diakui sebagai income dari kegiatan mengemis.

Ilustrasi kontradiktif pengemis kampung pragaan daya menuai komentar publik dengan sagala pro dan kontra sehingga peneliti tertarik untuk meneliti secara mendalam dan komprehensif terkait konsep 
mengamis di kampung pragaan daya. Selain megandung unsur kultur dan maraknya persoalan humaniora dalam konteks mengemis juga memiliki substansi nilai akuntansi sederhana terkait biaya dan pendapatan pengemis.

Berdasarkan uraian latar belakang diatas menimbulkan pertanyaan, apa latar belakang kehidupan pengemis di desa pragaan daya kecamatan pragaan kabupaten sumenep? dan apakah terdapat motif akuntansi dalam kegiatan pengemis di desa pragaan daya kecamatan pragaan kabupaten sumenep? dengan demikian peneliti tertarik untuk meneliti “Aspek Akuntansi Kehidupan Pengemis di Desa Pragaan Daya Kecamatan Pragaan Kabupaten Sumenep". dengan beberapa statement yang direalitas dengan fakta akurat, secara universal penelitian ini bertujuan untuk mengetahui latar belakang kehidupan pengemis di kampung pragaan daya dan mengeksplorasi motif akuntansi yang melekat dalam kegiatan mengemis secara kolektif.

\section{LITERATURE REVIEW Pengemis}

Pengemis erat kaitannya dengan keterbatasan ekonomi dan pengangguran. Di Indonesia pengemis bukan kata tabu, mengingat di setiap sudut daerah baik metropolis maupun pedasaan pengemis banyak ditemukan. Secara umum pengemis disamartikan dengan gelandangan. Menurut peraturan pemerintah republik indonesia no. 31 tahun 1980 pengemis diartikan sebagai orang yang mendapatkan penghasilan dari meminta-minta di depan umum dengan berbagai cara dan alasan dengan mengharap dikasihani oleh orang lain.

Pengertian senada juga disampaikan oleh Irawan (2010) yang menyatakan bahwa pengemis lazim digunakan dan ditujukan kepada orang yang tidak memiliki rumah, kelaparan dan tidak memiliki uang kemudian meminta-minta kepada orang yang ditemuinya. Pengemis akan menggunakan anekaragam cara untuk mendapatkan belas kasihan dan simpati dari orang lain dengan berpenampilan lusuh, tubuh kotor dan menggunakan gelas plastik atau plastik permen untuk dijadikan tempat penyimpanan uang dari hasil mengemis.

\section{Akuntansi dan Kehidupan Sosial}

Dalam kehidupan sosial akuntansi banyak ditemukan, dengan menggunakan istilah yang masih sederhana dan tidak bersifat ilmiah, seperti pengeluaran dan pemasukan. sempitnya pemahaman akuntansi dalam kehidupan sosial didorong dengan fakta bahwa pengertian akuntansi seputar dititik fokuskan kepada tehnik dan penghitungan. Di sisi yang berbeda Suwardjono (2011), Hofstede (1986) dan Mardiasmo (2002) berpendapat bahwa akuntansi tidak cukup berfokus kepada orientasi ilmu pengetahuan karena secara substansial terdapat seni yang terkandung di dalamnya. Dengan demikian, dalam pengembangan akuntansi dipengaruhi oleh beberapa hal seperti nilai budaya, sektor ekonomi, hukum dan peraturan, sistem, sosial dan politik di mana akuntansi berkembang.

Menurut Triyuwono (2006) akuntansi sebagai pengetahuan dan praktik yang dikonstuksi dan diyakini sebagai instrumen pengelolaan sosial. Akuntansi modern diyakini sebagai salah satu ilmu yang mengandung nilai egositik, Materialistik dan nilai utilitarianisme. Ketiga nilai tersebut sebelumnya pernah hidup dalam akuntansi yang dibatasi oleh sistem kapitalisme dan menjadi cikal bakal kehancuran ekonomi 
dunia. Tercermin dari penipuan yang dimulai dari unit terkecil akuntansi sampai yang terbesar. Itu tidak akan terjadi tanpa campur tangan akuntan. tidak mengherankan lagi mengapa Chamber akhirnya membuat pernyataan mengenai situasi ini. Chamber menggambarkan kasus ini sebagai "Penipuan terbesar di dunia keuangan selalu menghasilkan neraca yang diaudit oleh perusahaan akuntan ternama" (Ludigdo dan Kamayanti, 2012).

Berdasarkan pembahasan di atas, dapat dipahami bahwa akuntansi dapat berkembang berdasarkan konstruksi sosial dan tujuannya dapat diimplementasikan dengan baik. Bhurcell (1980) menjelaskan akuntansi sebagai cerminan kehidupan sosialnya dimana hal itu dilibatkan. Dengan mengacu pada pendapat bhurcell dapat diasumsikan bahwa lingkungan kapitalis membutuhkan akuntansi kapitalis, lingkungan sosialis membutuhkan akuntansi sosialis dan juga lingkungan syariah membutuhkan akuntansi syariah. Keterikatan budaya dan lingkungannya dengan akuntansi menunjukkan bahwa akuntansi adalah anak dari budaya lokal dimana ia tinggal (Zulfikar, 2008).

Pendapat tokoh sebelumnya juga dikuatkan dengan pendapat (Violet, 1983) yang menemukan bahwa budaya local memiliki peran penting yang mempengaruhi sistem akuntansi di suatu Negara, atau terletak pada bagaimana seorang di suatu Negara menggunakan informasi sistem akuntansi. (Gray, 1988) menjelaskan bahwa yang dipraktikkan bersama Negara tertentu akan mengubah nilai akuntansi dan akan terus mengubah sistem akuntansi di Negara bersangkutan. Pertiwi dan Ludigdo (2013) mencoba menerapkan CSR berdasarkan Tri Hita Karana, Saputra (2011) gabungan akuntansi dengan nilai lokal Subak, Bali.
Rizaldy (2012) membawa ke permukaan nilai-nilai lokal dalam budaya Jawa, ke kean (pemberi) dan selametan untuk membentuk konsep aset biologis. Randa dan Daromes (2014) mengubah nilai lokal budaya Toraja dalam membangun akuntabilitas sektor publik.

\section{Pengemis Juga (Ber) Akuntansi}

Dalam prosesi akuntansi pengemis, pengelolaan keuangan dapat dilakukan berdasarkan persamaan akuntansi, akan tetapi secara aplikatif tidak semua akun yang terdapat dalam persamaan akuntansi digunakan dalam prosesi akuntansi pengemis. Dikarenakan dalam praktik akuntansi pengemis hanya dibutuhkan penerimaan dan pengeluaransecara kasarnya saja.

Analisis yang dilakukan untuk mengetahui bagaimana aset bisa bertambah dan bagaimana mengelola asset tersebut sehingga pemenuhan lainnya dapat terpenuhi. Begitupula dengan kewajiban, mengurangi kewajiban pada pengelolaan keuangan prosesi pengemis adat Desa Pragaan Daya. Prosedur ini pada umumnya berlaku dalam pengelolaan keuangan prosesi pengemis adat Desa Pragaan Daya. Dimana transaksi yang terjadi pada umumnya dicatat secara sederhana sebagai perhitungan baik pada pemasukan maupun pengeluaran yang terjadi selama prosesi itu berlangsung. Pencatatan dilakukan sesuai dengan pemahaman Pengemis dengan nama dan nominal yang mudah dipahami. Bukti-bukti yang dapat ditemukan dalam prosedur ini biasanya berupa catatan kecil pengemis dalam mencatat pemasukan maupun pengeluaran yang terjadi.

\section{METHODS}

Jenis penelitian yang digunakan adalah jenis penelitian kualitatif interpretatif dengan pendekatakan fenomenologi. Penelitian 
fenomenologi berusaha mencari arti secara psikologis dari satu pengalaman individu terhadap suatu fenomena melalui penelitian yang mendalam dalam konteks kehidupan sehari-hari subjek yang diteliti (Herdiansyah, 2012).

Teknik pengambilan sampel dalam penelitian ini menggunakan metode snow ball sampling. Informan kunci dalam penelitian ini adalah Pengemis, informan pendukung kepala desa Pragaan Daya Kecamatan Pragaan dan untuk informan pendukung selanjutnya $\mathrm{KH}$ Maimun Mannan selaku Tokoh Agama, tokoh masyarakat serta aparatur desa lainnya.

Dalam mencari dan mengumpulkan informasi maka peneliti melakukan penelitian ini dengan cara, Observasi dengan melakukan pengamatan dan datang langsung kepada objek penelitian yaitu desa pragaan. Selanjutnya, Wawancara dilakukan dengan sumber-sumber informan yang dianggap berkaitan dengan penelitian ini seperti kepala desa, toko masyarakat, dan juga masyarakat. Peneliti juga menggunakan Dokumentasi sebagai pelengkap dari kedua tehnik sebelumnya baik berupa foto, rekaman, dan dokumen-dokumen yang berkaitan dengan penelitian terkait praktik dan biaya yang dikeluarkan oleh pengemis.

Adapun tahapan-tahapan untuk menganalisis data yang diperoleh, dimulai dari Pengumpulan data, dengan mencatat data yang diperoleh sesuai dengan hasil wawancara, dokumentasi, dan observasi di lapangan terkait dengan praktik akuntansi pengemis seperti bagaimana proses biaya dan pendapatan yang di peroleh. Kedua, Reduksi data, dimana peneliti merangkum dan memilih informasi inti yang sesuai dengan fokus penelitian. Tahap Ketiga, Penyajian data yang dilakukan dalam bentuk uraian singkat sehingga dapat memudahkan peneliti untuk memahami kondisi yang terjadi dan dapat menentukan tahap selanjutnya yang akan dikerjakan praktik akuntansi pengemis. Keempat, Penarikan kesimpulan dan verifikasi, dengan menarik kesimpulan dari data-data yang telah diperoleh dan diolah sebelumnya sehingga ditemukan suatu kesimpulan yang apik terkait dengan penelitian ini dengan berdasarkan data yang valid dari lapangan.

\section{RESULT AND DISCUSSION}

\section{Latar Belakang Kebiasaan Mengemis}

Mengemis merupakan kegiatan meminta-minta bantuan baik kepada perorangan atau lembaga yang identik dengan penampilan pakaian yang serba kumal sebagai sarana untuk mengungkapkan kebutuhan apa adanya dan dengan berbagai cara lain untuk menarik simpati orang lain. Berdasarkan penelitian yang dilakukan, mayoritas pengemis di desa pragaan daya sendiri tidak mengetahui secara jelas sejak kapan budaya mengemis itu muncul karena hanya menjalankan tradisi dari nenek moyang. Budaya mengemis dilakukan karena mereka berfikir tidak ada jalan lain untuk memenuhi kebutuhan hidup kecuali dengan mengemis.

Ada beberapa faktor yang menyebabkan masyarakat di desa pragaan memilih menjadi seorang pengemis, antara lain adalah sebagai berikut.

\section{Pertama, kondisi alam yang gersang.}

Kondisi alam di desa ini termasuk daerah yang tandus dan tanah berbatuan, tidak seperti daerah lain yang dalam satu tahun bisa menanam padi, jagung, tembakau, kacangkacangan dan keringnya air yang hanya menunggu datangnya musim hujan serta minimnya pengetahuan tehnik pengolahan pertanian. Faktor alam mempunyai pengaruh dalam membentuk mental dan sikap manusia. 
Meskipun di desa ini terdapat potensi ekonomi yang baik untuk dikembangkan berupa pohon siwalan, tetapi masyarakat tidak mengembangkan menjadi home industry dengan pengembangan teknologi tepat guna serta pengembangan sumber daya alam lainnya.

Kedua, kemiskinan. Terjadinya kemiskinan pada masyarakat pragaan daya lebih banyak disebabkan oleh faktor kultural. Kemiskinan yang menghinggap pada masyarakat Pragaan Daya bukanlah kemiskinan secara material, tetapi merupakan miskin pengetahuan yang mengakibatkan mental mereka kurang kreatif. Ketiga, Pendidikan. Dengan rendahnya pendidikan masyarakat pragaan daya mengakibatkan pola fikir mereka yang kurang maju, masyarakat pragaan daya beranggapan dengan rendahnya pendidikan yang mereka lalui mengakibatkan susah mencari pekerjaan, sehingga tidak ada jalan lain selain mengemis. Keempat, masalah sosial budaya. Sikap pasrah pada nasib yang menimbulkan keputusasaan karena pekerjaan yang mereka lakukan tiap hari seperti mencari kayu bakar, mengumpulkan batu-batu kecil di gunung yang kemudian dijual dirasa kurang mencukupi kebutuhan sehari-hari.

Dari berbagai masalah yang dihadapi membuat masyarakat pragaan daya mencari alternatif pekerjaan isntan dengan mengharapkan uluran tangan dan belas kasihan orang lain. Bagi pengemis yang sudah berumur 50 tahun ke atas, orientasi hidupnya diarahkan untuk pemenuhan biaya hidup dasar, sedangkan bagi kaum muda, orientasinya tertuju ke barang-barang seperti sepeda motor dan alat rumah tangga lainnya.

\section{Motif Akuntansi Pengemis: Perencanaan dan Akuntansi (dalam) Ingatan.}

Dari hasil observasi, ada dua motif akuntansi dalam praktik mengemis yaitu:

\section{Nilai akuntansi dalam aspek perencanaan}

Pengemis pertama kali melakukan profesinya secara individual, baik dalam hal keberangkatan maupun penentuan daerah operasi. Mereka menjalankan profesinya secara penuh waktu, berangkat pagi sekitar pukul enam dan pulang menjelang Maghrib. Perjalanan ketempat mengemis ditempuh dengan berjalan kaki bila jaraknya dekat. Namun bila jarak cukup jauh, mereka menaiki kendaraan. Secara tidak langsung pengemis telah menerapkan nilai nilai akuntansi dengan adanya perencanaan dan tujuan dasar, perencanaan operasional.

Pengemis dalam menjalankan pekerjaannya, rencana yang dilakukan oleh pengemis konvensional adalah Pertama, Individu. Pengemis individu biasanya beroperasi sesuai dengan keinginannya, artinya sasaran operasi tiap harinya bisa tetap dan bisa berubah. Ternyata dari hari ke hari dalam satu minggu para pengemis orangnya sama, hanya berbeda pembagian lokasi (antar RT/RW, antar gang atau antara jalan sisibarattimur/utara- selatan) dengan kata lain mereka telah menggunakan nilai yang terkandung dalam akuntansi yang berupa perencanaan (tujuan, sasaran, operasional). Pengemis tradisional yang beroperasi di Sumenep, Pamekasan biasanya pulang tiap hari. rata-rata mereka mulai Shubuh dan pulang kira-kira pukul 16.00, sehingga sampai di rumah sebelum terbenamnya matahari (Maghrib).

Seringkali para pengemis tradisional ini bermalam bahkan bermukim di desa lain. Bagi Ny. Rahmina (35 tahun), salah seorang informan (pengemis Pr) yang mengemis di Surabaya Dan tidak tentu pendapatan tiap 
harinya. uang paling sedikit Rp. 200.000,bahkan kalau untung sampai mencapi Rp.400.000,-. Tetapi beban hidup yang jauh lebih besar dari pada pendapatan yang diperolehnya. Dalam akuntansi ketika biaya lebih besar dari pendapatan maka yang diperoleh adalah kerugian. Jadi, rata rata pendapatan dari pengemis adalah $\mathrm{Rp}$. 300.000 .

Kedua,Gendong Bayi. Cara ini dilakukan oleh ibu-ibu yang mempunyai bayi tapi tidak tau mau dititipkan dan rumah tidak ada yang menjaga, dengan terpaksa harus membawa untuk ikut bersama. anak yang dogendong oleh pengemis tersebut adalah anaknya sendiri. Dilihat dari nilai akuntansinya, motif gendong bayi dijadikan strategi perencanaan operasi. Ketiga, Membawa Barang. Strategi ini dilakukan dengan cara membawa dagangan; jagung, gula merah, tembakau ke Jawa (luar Madura) untuk dijual. Setelah barang-barang terjual, mereka kemudian memakai pakaian pengemis. Jadi, mereka mendapatkan dua keuntungan, yaitu menjual barang dan minta uang. Waktu yang dihabiskan untuk melakukan strategi ini paling lama dua - tiga minggu. Sasaran operasi mereka adalah warga Madura yang hidup di Jawa, seperti Pasuruan, Jember, dan Probolinggo.

Terdapat unsur akuntansi dalam hal perencanaan yang sangat baik sehingga pemamfaatan waktu yang digunakan secara detail tanpa ingin ada kerugian. Para pengemis setelah mereka mendapat uang banyak, mereka pulang tidak membawa uang tapi membawa barang, seperti tikar untuk dijual ke Sumenep, dan setelah tikar tersebut terjual mereka berangkat lagi ke Probolinggo untuk beroperasi mengemis. Jadi ada nalar bisnis untuk mendapatkan hasil yang lebih banyak
Keempat, Menanti di Warung. Menurut hasil observasi peneliti, para pengemis jenis ini sering beroperasi di malam hari, mulai dari pukul 18.00 WIB - 23.00 WIB. Hal ini terlihat di sekitar jalan Seludang Sumenep dan di depan Toko Al Malik, dengan duduk di pojok warung dan toko dan menadahkan tangan kepada setiap orang yang selesai makan. Para pengemis ini rata-rata tiap malam mendapatkan maksimal Rp. 20.000,-. Kalau dijumlah dengan pendapatan pagi hari menjadi antara Rp. 40.000 - Rp. 65.000,dilihat dari sudut pandang akuntansi, terdapat unsur pendapatan dan beban di dalamnya dimana pendapatan yang diperoleh per harinya rata-rata adalah Rp. 52.500,sedangkan beban hidupnya meliputi beban makan 2 X Rp 7.000,- perhari beban ongkos tranportasi PP Rp. 10.000,-. Secara perhitungan untuk mencari laba bersihnya, Rp 52.500,- - Rp 24.000,- = Rp 28.500. Jadi, laba bersih dari profesi motif mengemis seperti ini per hari adalah $\operatorname{Rp} 28.500$.

Kelima, Pengemis Non Konvensional. Seiring dengan perkembangan zaman, maka model mengemispun mengalami dinamika yang cukup menarik sejak tahun 1980-an. Kegiatan mengemis mulai terorganisir dan diorganisir secara lebih rapi. Perkembangan yang paling menonjol adalah kemampuan mereka untuk mempetakan daerah sasaran operasi di luar kabupaten Sumenep dan pengembangan model pengemisan dengan cara-cara non konvensional.

Sedangkan pengemis secara nonkonvensional adalah mengemis dengan penampilan lebih rapi (mengenakan celana atau sarung lengkap dengan kopiah), membawa surat "resmi" dari lembaga atau yayasan dan surat jalan dari pemerintah. Pada prinsipnya masing masing individu bertanggung jawab atas keselamatan dirinya 
sendiri, dan juga masing-masing memiliki hak penuh untuk membelanjakan hasil mengemis. Meski demikian hubungan antar individu, terjaga dengan baik, minimal sesama anggota saling mengetahui situasi dan kondisi.

Sedangkan bagi pengemis yang dilakukan secara kolektif (non konvensional) segala sesuatunya telah disiapkan secara matang, seperti surat jalan, proposal dan alat kelengkapan lainnya. Sasaran operasinya adalah kota-kota besar seperti Jakarta, Semarang, Batam, Bandung dan sebagainya. awal mula munculnya pengemis dengan cara non-konvensional adalah karena mereka meniru suksesnya kegiatan pengumpulan dana untuk pembangunan masjid atau yayasan. Salah satunya Lembaga Pendidikan Yayasan Hidayatut Thalibin yang diasuh oleh KH. Maimun Mannan. Yayasan ini dibangun sebagaian besar dananya dikumpulkan dengan cara surat menyurat atau membentuk panitia pencari amal secara door to door dengan membawa proposal resmi.

Dalam pelaksanaan pencarian amal ini, pihak yayasan memberikan stimulan berupa prosentase kepada pencari sebesar 20 persen dari jumlah total pendapatan. Pemberian prosentase kepada pencari dana sebagai rangsangan dan pengganti kerja yang dihitung perhari. Praktik seperti ini terorganisir secara rapi, mulai tingkat desa sampai kota Kabupaten. Di tingkat desa, aktor yang mengorganisir biasanya orang yang memproses surat-surat kelengkapan administrasi pencarian dana, mulai dari pengurusan akte notaris sampai surat rekomendasi dari muspika. Sedangkan di kota besar, orang yang mengorganisir adalah orang (Madura) yang sudah lama menggeluti profesi mengemis dan mengetahui peta daerah mana yang perlu dijadikan obyek sasaran.
Proses terbentuknya pengelompokan pengemis di kota besar biasanya terjadi karena mereka sebelumnya sudah ada hubungan, baik melalui para sesepuh, senior atau keluarga yang pernah merantau di kota tersebut. Pada umumnya, mereka tidur dan makan di rumah temannya yang ada di kota dengan sistem membayar bulanan dan pulang minimal sebulan sekali, bahkan ada yang setengah tahun. Pada umumnya para pengemis ini pulang membawa uang dan ada pula yang membawa barang-barang kebutuhan keluarga, seperti barang-barang elektronik dan perabot rumah tangga lainnya.

Pengemis yang terhimpun dalam kelompok, biasanya mereka berangkat dari rumah secara bersama-sama, meski pulangnya seringkali tidak bersama-sama. Teknis kepulangan ini cukup bervariasi, ada sebagian anggota kelompok pulang setiap minggu, ada yang pulang setiap dua minggu, setiap bulan dan sebagainya. Bila dalam satu minggu atau sepuluh hari sudah mencapai target minimal, mereka bisa langsung pulang. Sebaliknya, bila tidak mencapai target minimal mereka menunda kepulangan.

\section{Akuntansi Ingatan}

Berdasarkan hasil dari wawancara peneliti, pengemis melakukan pencatatannya dengan cara pencatatan dalam pikiran dimana mereka sebatas mengingat tentang pendapatan yang di perolehnya serta beban-beban yang harus mereka tanggung. proses tentang pengelolaan keuangan akuntansi pengemis dapat dilakukan berdasarkan persamaan akuntansi, namun dalam penerapannya tidak semua akun digunakan dalam pengelolaan keuangan prosesi akuntansi pengemis. Dalam praktik akuntansi pengemis hanya dibutuhkan penerimaan dan pengeluaran secara kasarnya saja dan transaksi yang terjadi pada umumnya dicatat secara sederhana sebagai perhitungan 
baik pada pemasukan maupun pengeluaran yang terjadi selama prosesi itu berlangsung.

Pada pencatatan yang sederhana tersebut, Pengemis biasanya mencatat sesuai dengan pemahaman Pengemis terebut dengan nama dan nominal yang mudah dipahami. Dalam prosedur ini juga tidak terdapat pelaporan berupa laporan keuangan sebagaimana yang dijelaskan dalam persamaan akuntansi. Bukti-bukti yang dapat ditemukan dalam prosedur ini hanya berupa catatan kecil pengemis dalam mencatat pemasukan maupun pengeluaran yang terjadi. Pengemis hanya sebatas mengingat pendapatan dan biaya hidup yang dikeluarkan.

\section{CONCLUSION}

Berdasarkan hasil penelitian dan analisis yang telah dilakukan oleh penulis maka penulis menyimpulkan diantaranya adalah yang pertama, terdapat beberapa faktor yang melatarbelakangi masyarakat pragaaan daya menjadi seorang pengemis diantaranya, kondisi alam yang gersang terjadinya kemiskinan pada masyarakat pragaan, rendahnya pendidikan masyarakat pragaan daya mengakibatkan pola fikir mereka yang kurang maju, sikap pasrah pada nasib yang menimbulkan keputusasaan. faktor kedua, dalam budaya mengemis terdapat nilai nilai akuntansi seperti perencanaan tujuan dan sasaran dasar, perencanaan operasional, dan pengendalian. sedangkan proses tentang pengelolaan keuangan akuntansi pengemis dapat dilakukan berdasarkan persamaan akuntansi, dalam penerapannya praktik akuntansi pengemis hanya dibutuhkan penerimaan dan pengeluaran secara kasarnya saja.

Berdasarkan penelitian yang sudah dilakukan terhadap budaya di desa pragaan daya tersebut, maka saran peneliti untuk para peneliti yaitu adalah diperlukannya kembali pengembangan tentang akuntansi. Karena akuntansi bukanlah sebatas apa yang terbenak dalam pikiran kita selama ini, yaitu tentang teknik dan perhitungan tetapi akuntansi mampu tercipta dari kehidupan sosial, budaya, dan lain sebagainya. Selain itu bagi para pihak praktisi, yaitu diperlukannya sorotan lebih dari pemerintah terkait diskriminasinya budaya ini. Mungkin dengan adanya pelatihan dan lain semacamnya sehingga ekonomi kerakyatan dapat terealisasikan dan mengurangi angka kemiskinan. Bagi masyarakat sendiri dengan adanya beberapa modus atau cara cara yang dilakukan pengemis tidak mengurangi kita dalam saling membagi rezeki yang kita punya, karena memang banyak dari mereka yang masih membutuhkan. Bagi pengemis sebaiknya gunakan softskill yang kalian punya untuk mengembangkan martabat hidup kalian tanpa harus melakukan dan meneruskan budaya ini. Tanpa harus menunggu pemerintah yang pasti dengan cara dan mendapatkan rezeki yang halal.

\section{REFERENCES}

American Institute of Accountants, Report of Committeeon Terminologi, Committee on Accounting Procedure, Amerika Serikat., 1940

Accounting Association. Committee to Prepare a Statement of Basic Accounting Theory American. A statement of Basic Accounting Theory. Amerika Serikat, 1996.

Suwardjono., Teori Akuntansi Pekerayasaan Pelaporan Keuangan, Ketiga. Yogyakarta:BPFE,2011.

Thalid, Mohammad Anwar. 2017. "The Importance of Accounting Investigation 
in Wedding Ceremonyin Gorontalo". Imperial Jurnal of Interdisciplinary Research (IJIR). Department of Postgraduete Economic and Business, Brawijaya University, Indonesia. Vol 3, Issue 1

Triyuwono, Iwan. 2015. Akuntansi Malangan : Salam Satu Jiwa Dan Konsep Kinerja Sepak Bola. Jurusan Akuntansi Multi Paradigma, Vol. 6, No. 2, Pp. 290-303

Rahayu, Sri, Yudi Dan Dian Purnama Sari. 2016. "Makna Lain Biaya Pada Ritual Ngaturang Canang Masyarakat Bali”

Alkostar, Artidjo, Advokasi Anak Jalanan, Jakarta;Rajawali; 1984

Creswell, J. W., Research Design: Qualitative And Quantitative Approaches. London: Sage Publications, 1994.

Lewis, Oscar, Five Families; Mexican Case Studies In The Culture Of Poverty, 1959.

Suparlan, Parsudi, Gelandangan: Sebuah Konsekuensi Perkembangan Kota, dalam Gelandangan Padangan Ilmu Sosial, Jakarta: LP3ES, 1986, hlm. 30.

Al Humaidy, Ali. 2009. Pergeseran Budaya Mengemis Di Masyarakat Desa Pragaan
Daya Sumenep Madura. Tersedia pada http://ern.pendis.kemenag.go.id/Dok Pdf/ern-III-04.pdf pergeseran budaya mengemis (diakses pada 6 desember 2010)

Arikunto, Suharsimi. 2006. Prosedur Penelitian Suatu Pendekatan Praktik. Jakarta: PT. Rineka Cipta.

Arraiyyah, Hamdar. 2007. Meneropong Fenomena Kemiskinan Telaah Perspektif Al-Qur'an. Yogyakarta: Pustaka Pelajar

Chalik, Abdul. 2006. Tradisi Mengemis Di Kompleks Makam Sunan Giri Kecamatan Kebomas Kabupaten Gresik. Tersedia Pada Http://Journal.Unai.Ac.Id/Filerpdf/Peny andang\%20masalah\%Kesejahteraan20s osia/Pdf (Diakses Pada 10 Oktober 2007)

Djamaluddin, Dasman. 2010. Penanggulangan Gelandangan Dan Pengemis. Tersedia pada http://.wikimu.com/News/DisplayNews. aspx?id=15205 (diakses pada 3 April 2011) 